\title{
A REVIEW AND INVESTIGATIONS OF SOME PROPERTIES OF FOAMED AERATED CONCRETE
}

\author{
E. Ikponmwosa ${ }^{1}$, F. Falade ${ }^{2}$, C. Fapohunda ${ }^{3, *}$ \\ 1,2 Department of Civil and EnVironmental EngineERING, University of LAGos, Nigeria. \\ ${ }^{3}$ DePartment OF BuILDing, CALEB University, IMOTA LAGos, NigERIA. \\ E-mail Addresses: ${ }^{1}$ efe_ewaen@yahoo.com, ${ }^{2}$ ffalade@hotmail.com, ${ }^{3}$ fapohunda07@yahoo.com
}

\begin{abstract}
The paper presents the results of investigation conducted on foamed aerated concrete - a lightweight concrete - with a view to determining its potential as a construction material in Nigeria. The properties investigated on foamed aerated concrete having a designed density of $1600 \mathrm{~kg} / \mathrm{m}^{3}$ were: workability, density, compressive strength, tensile strength, and the water absorption capacity. The results showed that at the designed density adopted for this work, the material was workable and repeatable. Other results at 28 days of curing are: (i) compressive strength of $15.43 \mathrm{~N} / \mathrm{mm}^{2}, 13.89 \mathrm{~N} / \mathrm{mm}^{2}$ respectively for air-cured and water-cured specimens, (ii) modulus of rupture of $2.53 \mathrm{~N} / \mathrm{mm}^{2}$ (ii) splitting tensile strength of $1.63 \mathrm{~N} / \mathrm{mm}^{2}$, and (iv) the water absorption capacity of $1.03 \%$.The tensile strength to compressive strength ratio was more than $10 \%$. These properties improved with time. It can be concluded that the foamed aerated concrete used for this work is repeatable, and of adequate strength for use as a construction material.
\end{abstract}

Keywords: Aerated Concrete, Compressive Strength, Tensile Strength, Workability

\section{Introduction}

Concrete has become the premier and the most favoured of all the construction materials of construction, because it can be produced in a variety of strengths, stiffnesses, unit weights, porosities and durability characteristics and properties, by using the same four basic components of cement, fine sand, coarse sand and water. The fact that it allows innovations and creativity in its production, either by altering its composition during mix designs, or by the addition of chemical admixtures like superplasticizers, or by adding mineral additives like fly ash, granulated blast furnace, silica fume, etc. has led to the development of many types of concrete with different properties, which are later used for specialized applications. One of such type of concrete is aerated concrete, a construction material that is yet to be developed in Nigeria [1].

According to [2], aerated concrete is either cement or lime mortar, classified as lightweight concrete, in which air voids are entrapped in the mortar matrix by means of a suitable aerating agent. Its density is between 300 and $1950 \mathrm{~kg} / \mathrm{m}^{3}$ [3]. It is also regarded as cellular concrete because of its internal system of unconnected cell-like voids that is the result of the aeration process. Traditionally, aerated concrete consists of cement, sand, foaming agent and portable water. In some instances, cement can partially be replaced by lime, silica fume, fly ash. Ground slag, fly ash, and other wastes product can also be used in place of sand.Although it was initially envisaged as an insulating material, there is now a renewed interest on its constructional characteristics in view of its lighter weight which results in significant savings in materials consumption.

Aerated concrete can be classified in a number of ways. Firstly, on the basis of method of poreformation, it can either be gas concrete or foamed concrete. It is gas concrete, when the pore is foamed through the process of chemically-based air-entrainment, while foamed concrete is formed through mechanical means [4]. Secondly, it can be classified according to the binder used: whether cement, or lime, or blended cement, or other industrial wastes like finely-grinded blast furnace granulated slag, fuel ash, etc. Another method used for its classification is based on the method of curing. When it is subjected to high pressure

* Corresponding author: Tel.: +234-08085226338. 
steam curing, it is called autoclaved aerated concrete (AAC). Any aerated concrete produced through other form of curing are collectively regarded as Non-Autoclaved aerated concrete (NAAC).

Aerated concrete is also regarded as "cellular concrete" because of its internal cellular structure which consists of millions of non-connected air cells resulting from the aeration process.Irrespective of its classification, properties of aerated concrete are the same, which are: thermal and sound insulation, fire resistance, lightweight, and moderate strength. Table 1 shows the typical properties of aerated concrete.

Table 1: The typical Properties of Aerated Concrete [5]

\begin{tabular}{cccc}
\hline $\begin{array}{c}\text { Dry } \\
\text { Density } \\
(\mathrm{Kg} / \mathrm{m} 3)\end{array}$ & $\begin{array}{c}\text { Compressive } \\
\text { Strength } \\
(\mathrm{MPa})\end{array}$ & $\begin{array}{c}\text { Elastic } \\
\text { Modulii } \\
(\mathrm{GPa})\end{array}$ & $\begin{array}{c}\text { Thermal } \\
\text { Conductivity } \\
(\mathrm{W} / \mathrm{m} . \mathrm{k})\end{array}$ \\
\hline 400 & 1.00 & 1.00 & 0.10 \\
600 & 1.50 & 1.50 & 0.11 \\
800 & 2.00 & 2.50 & 0.20 \\
1000 & 5.00 & 3.00 & 0.30 \\
1200 & 10.00 & 4.00 & 0.40 \\
1400 & 15.00 & 6.00 & 0.55 \\
1600 & 25.00 & 12 & 0.65 \\
\hline
\end{tabular}

It is now becoming possible, through mix composition, to develop aerated concrete with strength sufficient enough to break the limit of its current sphere of application $[6,7,8]$. The initial compressive strength limit of about $10 \mathrm{~N} / \mathrm{mm}^{2}$ is now being exceeded through material composition. For example, [6] developed aerated concrete of compressive strength in excess of $25 \mathrm{~N} / \mathrm{mm}^{2}$ by using fine fly ash as partial replacement of cement and coarse fine ash as partial replacement of sand. Superplasticiser and polypropylene fibres were also included in it. Though the tensile strength was still low, they were able to overcome this by using fibre as reinforcement. A compressive strength in excess of $40 \mathrm{~N} / \mathrm{mm}^{2}$ by the use of superplasticizer in the mix composition was obtained by [7]. By using silica foam in the mix [8] were able to obtain a compressive strength of $50 \mathrm{~N} / \mathrm{mm}^{2}$. With these results, the possibility of breaking the strength limit, which has constituted itself into barrier that prevent full scale adoption and utilization of foamed concrete for major construction works is brightening by the day. From its initial beginning when the first patent was granted in 1928 to a Swedish Architect, its production has gradually increased, and it has subsequently been adopted in many countries, so that it is now being manufactured in more than 35 countries worldwide [9]. It is now reported that aerated concrete now accounts for over $40 \%$ of all construction in the United Kingdom and more than $60 \%$ of construction in Germany [10]. From the countries of Europe, its usage has spread to Malaysia, Singapore, India, Australia, United Arab Emirate, and recently America. There is however some characteristics, which have enhanced its applications in diverse constructions, and that have thus aided this apparent rapid spread to many countries. The background to this study was founded on the need to bring to the fore those characteristics and properties that have led to the rapid spread formed aerated concrete; intended to serve as impetus for the development of the Nigeria version of the material.

\subsection{Characteristics and Properties of Aerated Concrete and Products}

\subsubsection{Flowability}

The flowability of foamed concrete is characterised by the fact that it is selfcompacting, free flowing and pumpable in the plastic state. This not only makes it easy to work with, but also eliminate the need for compaction, thereby leading to savings. The fact that it is pumpable makes it to be useful in inaccessible areas

\subsubsection{Workability}

Aerated concrete can be worked upon in all manners. It can be cut with hand saw to desired dimension including angles and other shapes. It can also be drilled into, nailed into, grooved, routed, shaped, curved, coated, etc and finished with paint, tile, plaster or veneer. This makes aerated concrete an adaptable product to work with, thus allowing flexibility in construction [11].

\subsubsection{Thermal Insulation}

Aerated concrete is an energy-efficient building material because it has high thermal capacity, or ability to absorb and retain relatively large amounts of heat energy. The effects are to minimize heat loss during cold weather and maximize heat gain during warm weather. Low density and high porosity combined to make aerated concrete exhibit these characteristics. Its porosity results in low thermal productivity, 
while its low density gives the material a thermal mass that enhances thermal performance.

\subsubsection{Sound Insulation}

Because of its independent air cells, which dampen sound transmission, aerated concrete has excellent and sound insulation and absorption capacities. This eliminates the use of other insulating materials like fiber glass. This has made it most suitable for construction of Hotels, entertaining facilities, multi-user apartment's freeway sound walls, and in buildings that require acoustic ability.

\subsubsection{Fire resistance}

Aerated concrete has a melting point of over $1500^{\circ} \mathrm{C}$, and provides approximately twice the fire resistance of normal concrete. For example, a 4inch non-loadbearing wall of aerated concrete without surface finishes has a fire resistance of 4hours, while that of similar non-load bearing concrete block wall has a fire resistance of 2 hours [9]. Thus the use of aerated concrete eliminates the use of any additional fire-proofing materials and the amount of concrete cover when used as structural elements.

\subsubsection{Wide range of densities}

Aerated concrete can be produced to have a wide range of densities $\left(300-1950 \mathrm{~kg} / \mathrm{m}^{3}\right)$, with proper control in the dosage of the foam, materials selection and materials composition. This has increased tremendously the scope into which aerated concrete can be put into use.

\subsection{Potential Applications of Foamed Aerated Concrete}

\subsubsection{Architectural Applications}

a. Roofing and Flooring Insulation: By choosing a very low density mix of between $300-600 \mathrm{~kg} / \mathrm{m}^{3}$, the thermal and insulating properties of foamed concrete can be utilized and applied as a roof and floor insulation against heat and sound. It does not add to the overall weight of the roof. It is a suitable material in all situations where insulation is required.

b. Fire Breaks: It is used as firebreaks in buildings where there are large undivided spaces because of its excellent fire resisting qualities. It also prevents flame penetration.

c. Partitions: In form of precast blocks and panels, foamed concrete is used for partitions and curtains walls in all types of building structures. d Ornamental: Foamed concrete are used to produce architectural ornamental products in wide range of finishes, such as marble, sandstone, slate of any colour. The product range includes columns, bench tops, ledges, arches, ties, etc. or anything which can be cast in moulds. Sculpturing works are also possible with aerated concrete.

\subsubsection{Foundation and Geotechnical Applications}

a. Trench Reinstatement: Foamed concrete is an ideal material for trench reinstatement that is dug in roads when pipes are laid or repairs carried out. It is advantageous over granular materials in that it does not settle nor does it requires compaction. Because of it light weight, it will not damage pipes, and its fluidity ensures that all voids and cavities are completely filled.

\section{b. Bridge Abutment:}

Its light weight makes it to have an edge over granular materials as a "backfill" material for bridge abutment, because it will not impose large lateral load on the bridge wall, thereby reducing active pressures. The practical elimination of lateral load results in the use of reduced sections for thickness of the bridge walls and the size of the foundations. It does not require compaction, and neither will it sink into the sub soil to cause sinking and subsidence of the road.

c. Road Sub Base: The use of aerated concrete as sub-base materials in road construction, especially where the ground is soft, makes road structures to be less heavy. This is one way of eliminating roads settlement of roads, especially I areas of soft ground

d. Ground Works: Foamed concrete are used for myriads of ground works such as soil stabilization, highway widening schemes, land reclamations and filling of harbours. It is also ideal for road foundations. This is because it does not sink to the ground.

e. Tunnelling: Formed concrete presents itself as an ideal material for repair and construction of tunnel and underground chambers. It is used both for the filling of voids created and exposed during tunnelling. It is also used for grouting the finished works and gaps left behind the tunnel lining.

\subsubsection{Structural Applications}

Foamed concrete is yet to be used for full-scale structural applications because of its relatively 
low compressive strength; nevertheless, it is being employed in three categories of construction activities when some substances like super-plasticiser and fibres, etc. are incorporated into the mix. These are:

\section{a. In the production of masonry blocks: Aerated} concrete are used for making of foamed concrete blocks, which are for both load bearing and nonload bearing walls. These blocks are used for large scale construction of low cost housing units, family units, and low-rise buildings. An example is the School of Engineering building in Brescia, Italy. In this building, aerated concrete blocks was employed to perform the dual role of loadbearing external wall and insulating functions [12].

b. In the production of panels: The panels are being utilized for the construction of the outer walls of commercial buildings, outer walls of industrial buildings, outer walls of factories.

c. Integrated: It is being used as an integrated or composite system with concrete, or steel, or timber construction. In some cases brick panels were installed without mortar on a steel frame structure supported by an aerated concrete wall [12]. Aerated foamed concrete can also be used in roof of houses in system of foamed Concrete and slab integrated Constructions [13].

\subsection{Benefits of Using aerated Concrete}

\subsubsection{Low initial Capital.}

Initial investment on equipment for the production of foamed concrete is low. Foamed concrete can be produced on a small scale, even at site level, and it is relatively easy to place and finish without heavy or expensive equipment

\subsubsection{Availability and accessibility of principal materials.}

The materials for the production of foamed concrete are naturally occurring materials which are also easier and cheap to procure. These fundamental materials are Portland cement, sand, foaming agent, and water. It has also made possible large scale utilization of industrial waste products like, fly ash, silica fume, blast furnace slag, etc.

\subsubsection{Low materials Utilization.}

Aerated concrete consumes a relatively small amount of raw materials relative to the amount of finished product produced, when compared to other building materials. This is explicit from the work of Schnitzer [11].

\subsubsection{Low energy}

According to Schnitzler [11], aerated concrete consumes approximately $50 \%$ and $20 \%$ less energy than that is needed to produce concrete and concrete masonry.

\subsubsection{Lightweight}

Significant weight reduction ranging from between $20 \%$ to $80 \%$ depending on $\mathrm{mix}$ proportions and materials results in savings in structural elements sizes and areas of reinforcement

\subsubsection{Sustainability}

Aerated concrete is manufactured from readily available raw materials - sand, cement, lime, and water. Its products are also very recyclable. This ensures sustainability of production.

\subsubsection{Versatility}

The versatility of aerated concrete is in its system; and this include reinforced and unreinforced walls, slabs, roof panel on one hand, and building blocks of various sizes and shapes on the other. This ensures its utilization as a primary load bearing structural materials. It is also utilized as claddings on steel and concrete structures. The fact that it combines both structural and insulating qualities also enhanced its versatility.

\subsubsection{Eco-friendly}

Aerated concrete is remarkably eco-friendly. Aerated concrete is manufactured from inorganic and non-toxic raw materials [11]. Its manufacturing process is also devoid of production of pollutants or toxic substances [11]. And its products are recyclable, thereby reducing the amount of waste release into the environment. It also does not contaminate the environment during natural disasters like earthquake, hurricane, fire outbreak, etc, because of its excellent thermal qualities. It saves depletion of the top-soil, while at the same time it can actually use industrial waste like fly-ash, ground granulated blast furnace slag, etc. as one of its major constituents. The production process of aerated, or it's use does not release any harmful effluents to ground, water or air (unlike smoke of brick kilns and ruining of top soil in 
production of bricks). Its lightweight makes it ideal for making partitions, thus reducing the need for plywood partitions. This consequently will result in reduction in deforestation and will benefit environment. All these make it to be friendly to the environment.

Despite these properties, wide spectra of applications, and benefits derivable from its usage, no notable application is yet to be witnessed in Nigeria. Paucity of data based on experimental investigations done with locally available materials and technology is not helping matters. Earlier work done by [3] reported a compressive strength of about $3.45 \mathrm{~N} / \mathrm{mm}^{2}$. This value fell short of the strength requirement for structural lightweight concrete according to both [14] and [15] classifications. According to [14]a minimum of $3.50 \mathrm{~N} / \mathrm{mm}^{2}$ is required while [15] requires a compressive strength of $7 \mathrm{~N} / \mathrm{mm}^{2}$. This work intends to address the issue. Thus the aim of this work is to investigate some properties of foamed aerated concrete in Nigeria produced with locally available materials and technology as a way of assessing its potential as a structural material. The properties investigated included density, compressive strength, tensile strength, and water absorption capacity.

\section{Materials and Methods \\ 2.1 Materials and Mix Proportion}

The basic materials for the production of foamed aerated concrete are: binder, fine aggregates, foaming agent, and water. The binder used for this work the ordinary Portland cement produced in accordance with [16]. The fine aggregate was river sand having specific gravity of 2.66, obtained from upland source of Ogun River to ensure that it has low chloride content and organic impurities, and all size particles passing through $2.36 \mathrm{~mm}$ sieve. This is because the works of [2] has shown that higher compressive strength can be obtained by using sand with finer particle sizes. The foaming agent was proteinbased with trade name Lithofoam SL 200L. Available literatures [17], and [18]) revealed that foamed aerated concrete of structural value can be produced at densities between 1200 and $1900 \mathrm{~kg} / \mathrm{m}^{3}$. A density of $1600 \mathrm{~kg} / \mathrm{m}^{3}$ was adopted as the basis for the production foamed aerated concrete used for this work, as earlier used by Jones and McCarthy (2005), and subsequent evaluation of its characteristics. The trial mix was carried out using the equations suggested by [6]: Plastic Density $=\mathrm{c}+\mathrm{W}+\mathrm{f}$
$\mathrm{W}=\left(\frac{w}{c}\right)(\mathrm{c}+\mathrm{f})$

where $c$ is the cement $\left(\mathrm{kg} / \mathrm{m}^{3}\right), \mathrm{W}$ is water $\left(\mathrm{kg} / \mathrm{m}^{3}\right)$, $\mathrm{f}$ is fine aggregate $\left(\mathrm{kg} / \mathrm{m}^{3}\right), \frac{w}{c}$ is the water cement ratio.

The mix design (by weight) to produce the density of $1600 \mathrm{~kg} / \mathrm{m}^{3}$, with a tolerance of $100 \mathrm{~kg} / \mathrm{m}^{3}$ [6] was found to be: (i) cement to sand ratio, 1: 3 ; water to cement ratio, 0.5 , foaming agent to water, 1: 25 , and foaming agent to sand ratio, 0.0025:1.

\subsection{Production Techniques}

Having determined the mix proportions, the materials constituting base material mix - sand, cement, and water - were batched into the conventional concrete mixer and mixed to form the mortar. The pre-foamed solution prepared in a tank by diluting the foaming agent in water was fed into the mortar in the concrete mixer through the foam generator (the only additional equipment), where the required foam is generated.

\subsection{Experimental Investigations of Properties}

The following structural investigations were conducted on the foamed aerated concrete.

\subsubsection{Sand Properties}

The mechanical analysis was carried out on the sand to determine the particle size distribution by using the sieve analysis in accordance with [19]. The specific gravity was also determined using the specific gravity bottle.

\subsubsection{Workability Test}

The slump test was carried out in accordance with the provisions of [20].

\subsubsection{Wet Density Test}

The wet density of the foamed concrete was determined according with [21] from the weight of a fresh sample in a container of known volume and weight for each of the batches before it was cast in mould. The density was then calculated by dividing the difference in the weight of concretefilled container and the weight of the empty container by the volume of the container.

\subsubsection{Compressive Strength Test}

Compressive strength was measured at measured at $7,14,21,28,56$ and 90 days using $150 \mathrm{~mm} \mathrm{x}$ $150 \mathrm{~mm} \times 150 \mathrm{~mm}$ cube specimens, essentially in accordance with [22]. Two curing methods were employed: water- and air- curing. The water- 
cured specimens were tested at saturated state (immediately after removal from curing tank). The strength characteristics of each cube were determined on 600KN Avery Denison Universal Testing Machine at a loading rate of $120 \mathrm{KN} / \mathrm{min}$. Three specimens for each of the curing ages were tested to failure by crushing, and the maximum load recorded. The average of the three specimens was then taken and divided by the area of the specimens to obtain the compressive strength. A total number of 36 cube specimens were cast and tested.

\subsubsection{Splitting Strength Test}

The splitting tensile strength was carried out on the foamed concrete in accordance with the provision of [23] for lightweight concrete and [24]. The specimens were $150 \times 150 \times 300$ cylinders. They were water-cured for 7 days, followed by dry curing until the day of testing [23]. The splitting strengths were determined on 600KN Avery Denison Universal Testing machine at a loading rate of $120 \mathrm{KN} / \mathrm{min}$ until failure. The splitting tensile strength $\left(\mathrm{T}_{\mathrm{s}}\right)$ is then calculated as follows:

$T_{s}=2 \frac{P}{\pi l d}$

where: $\mathrm{T}_{\mathrm{s}}$ is the splitting tensile strength $\left(\mathrm{N} / \mathrm{mm}^{2}\right), \mathrm{P}$ is the maximum applied load (in Newtons) by the testing machine, $l$ is the length of the specimen $(\mathrm{mm})$, and $\mathrm{d}$ is the diameter of the specimen $(\mathrm{mm})$.

\subsubsection{Modulus of Rupture.}

The flexural strength of foamed concrete was determined by using a simple unreinforced beam subjected to a third point loading. The beam specimens were produced, prepared and tested in accordance with the provisions of [25] and [26]. The text specimens were $150 \times 150 \times$ $750 \mathrm{~mm}$ beams, and they were was tested under the third point loading test. The Modulus of Rupture $\left(\mathrm{M}_{\mathrm{r}}\right)$ is calculated as:

$M_{r}=\frac{P L}{b d^{2}}$

where: $\mathrm{M}_{\mathrm{r}}$ is the modulus of rupture $(\mathrm{MPa}), \mathrm{P}$ is the maximum applied load $(\mathrm{N}), \mathrm{L}$ is the span $(\mathrm{mm}), \mathrm{b}$ is the average width of the specimen at the failure $(\mathrm{mm}), \mathrm{d}$ is the average depth of the specimen at the failure $(\mathrm{mm})$. All the specimens tested failed within the middle third of the beam length.

\subsubsection{Water Absorption Capacity}

The water absorption capacity tests of foamed aerated concrete with and without pulverized bone were carried out in accordance with provisions of [27].

\subsection{Results and Discussions 3.1 Preliminary Results}

\subsubsection{The Properties of the Sand}

From the results of the sieve analysis performed on the River sand, the properties are: specific gravity: 2.59, coefficient of uniformity $(\mathrm{Cu}): 2.0$, coefficient of curvature (Cc): 1.2, fineness modulus: 1.89. All these results showed that the sand is fine and suitable enough for the production of foamed aerated concrete [28].

\subsubsection{Workability}

Foamed concrete is a free-flowing, self-levelling material and should therefore be expected to give a collapse slump. Thus neither the slump test [20] for normal weight concrete nor the flow test [29] for concrete with a high slump are applicable. Usually, therefore, the workability of foamed concrete is evaluated visually: in most cases it would not be difficult to spot when workability was unacceptably low [30]. But for the high density adopted for this work, it was obvious, from visual inspection that carrying out slump test would be appropriate. Subsequent slump test carried out in accordance with [20], showed that the average value of slump for the specimens tested was $50 \mathrm{~mm}$. At this slump, the material still maintain its selfcompacting properties, so that no compaction was needed for all the specimens produced and tested in this investigations. This also agrees with [31] that concrete with slump of between 25 and $50 \mathrm{~mm}$ requires no compaction by vibration.

\subsubsection{Wet Density and Repeatability of the Production Process}

The average wet density of the foamed aerated concrete was found to be $1668.28 \mathrm{~kg} / \mathrm{m}^{3}$, with the coefficient of variation of 3.69. The value of density was within the acceptable tolerance, and the coefficient of variability of less than $10 \%$ was also an indication of the satisfactory repeatability of production process at the designed density of $1600 \mathrm{~kg} / \mathrm{m}^{3}[6]$.

\subsubsection{Stability of the Foamed Concrete}

The ratio of wet density to the designed density is a measure of the stability of the foamed concrete produced. 
Table 2: The Characteristics of the Foamed Aerated Concrete

\begin{tabular}{lccc}
\hline Property & 28-Day & 60-Day & 90-Day \\
\hline Testing Density $\left(\mathrm{kg} / \mathrm{m}^{3}\right)$ & & & \\
- air cured & 1662.78 & 1669.56 & 1671.00 \\
- water cured & 1689.29 & 1713.75 & 1714.00 \\
\hline Compressive Strength $\left(\mathrm{N} / \mathrm{mm}^{2}\right)$ & & & \\
- air cured & 15.43 & 17.96 & 17.96 \\
- water cured & 13.89 & 16.78 & 16.90 \\
\hline Tensile Strength $\left(\mathrm{N} / \mathrm{mm}^{2}\right)$ & & & \\
- splitting strength & 1.63 & 2.26 & 2.62 \\
- modulus of rupture & 2.53 & 2.81 & 2.85 \\
\hline Water Absorption Capacity $(\%)$ & 1.03 & - & - \\
\hline Ratio of Strengths* & & & \\
- splitting to compressive & 0.13 & 0.15 & 0.15 \\
- modulus of rupture to compressive & 0.19 & 0.18 & 0.19 \\
\hline
\end{tabular}

* the cube strengths were converted to the equivalent cylinder strengths by multiplying the cube strengths by 0.85 [34]

To be stable, means the foam, in the form of air bubbles, is able to go through the whole production process without collapse. The value of the ratio must tend towards unity for stability [32] and [33]. The value of the ratio obtained for this work was 1.04. This value is close to unity, thus the foam concrete used for this work at the designed density is stable.

\subsection{Structural Characteristics}

The fundamental structural characteristics of the foamed aerated concrete used for this investigation were as shown in Table 2.

It can be observed from the table that the densities for all the specimens, at all the curing ages adopted for this work, were within the range for light weight concrete (less than $\left.1950 \mathrm{~kg} / \mathrm{m}^{3}\right)$. This is particularly important if the results of this investigation were to be considered valid for lightweight concrete, which is the object this investigation. The densities increased with curing ages for both water-cured and air-cured specimens. The increased could be a result of the pore-refining effects that the continued formation of $\mathrm{C}-\mathrm{S}-\mathrm{H}$ gel resulting from hydration has on the matrix of the internal structure. The water-cured specimens however developed higher densities than the air-cured specimens. This might be due to the contribution of pores water, in the matrix of the specimens,to its weight.For structural applications, compressive strength at 28 days of curing is considered to be the index of concrete quality [35]. From the Table 2, it can be observed that the compressive strength at 28 days curing varies from $15.43 \mathrm{~N} / \mathrm{mm}^{2}$ to $13.89 \mathrm{~N} / \mathrm{mm}^{2}$ respectively for air-cured and water-cured specimens. This strength meets the requirement for structural lightweight concrete according to both [14] and [15] classifications. A minimum

* Corresponding author: Tel.: +234-08085226338. compressive strength of $3.50 \mathrm{~N} / \mathrm{mm}^{2}$ is required by [14] while [15] requires a compressive strength of $7 \mathrm{~N} / \mathrm{mm}^{2}$. Also, [16] requires that the materials to be used for blocks, both for loadbearing and non-load-bearing purposes, should have a minimum compressive strength of $3.45 \mathrm{~N} / \mathrm{mm}^{2}$ and above.It is however to be observed that air-cured specimens developed higher strength than water-cured specimens at all the curing ages. This trends agreed with [3], even though the strength development in their works were considerably lower than the values obtained in this investigations. The compressive strength at both 60-day and 90-day for air-cured specimens remain the same, while the compressive strength for the water-cured specimens continues to increase. The reason may due to the availability of water to continue the strength-forming hydration process in watercured specimens. Non-increase in the strength of air-cured specimens may have suffered from the absence of water to sustain the hydration process. Both the splitting tensile strength and the modulus of rupture increased with curing age. The values obtained for the modulus of rupture were however higher than the values obtained for splitting tensile strength. But the rate of increase decreased with curing ages from $55 \%$ at 28 -day curing to about $1 \%$ at 90 -day curing. The tensile strength as determined from the modulus of rupture, important from the perspective of pavement and runway design, can be assessed by relating it to the compressive strength. This is $19 \%$ of the compressive strength at 28 days of curing.For concrete with compressive strength of less than $25 \mathrm{~N} / \mathrm{mm}^{2}$, the ratio of modulus of rupture to compressive strength has been found to be between $8 \%$ and $11 \%$ of the compressive 
strength [36]. Also the value obtained for the ratio of the splitting tensile strength to the compressive strength at 28 days of curing was higher than the generally accepted value of $10 \%$ of compressive strength for low-strength concrete [37].Thus tensile strength, measured in terms of both modulus of rupture and the splitting tensile strength can thus be considered as adequate.The water absorption capacity as obtained from this work was $1.03 \%$. This is a measure of its ability to withstand liquid-based agents of deterioration in the domiciled environmental. Concrete with water absorption capacity of less than $10 \%$ is considered good [31]. This clearly meets the requirement of [16] water absorption capacity of less than 12 for materials that is to be used for blocks both for load-bearing and non-load-bearing purposes.

\section{Conclusions}

From the above results, obtained from the investigation conducted on foamed aerated concrete, with a view to determining or otherwise its potential for use as construction material in Nigeria, the following conclusions are made:

1) The foamed aerated concrete used for this investigation is workable

2) The results also show that the material is stable and repeatable.

3) The compressive and tensile strengths are adequate for structural and construction application according to both national and international standards.

4) The mix proportion used in this work can be considered as suitable model for foamed concrete mixes.

\section{References}

[1] Falade, F. and Ikponmwosa, E. (2008) "An Overview of Foamed Aerated Concrete - A Building and Civil Engineering Construction Material". Journal of Engineering Science and Technology, Vol. 3, No. 3, pp. $5-14$.

[2] Narayanan and Ramamurthy (2000)"Structures and Properties of Aerated Concrete:A Review". Cement and Concrete Composites, Vol. 22, pp. 321 - 329.

[3] Falade, F. A., Ikponmwosa, E. E. and Arogundade, A. (2011) "Investigations of Some Structural Properties of Foamed Concrete". Journal of Engineering Research, Vol. 16, No. 1, pp. 67 - 80.

[4] Valore, R. C. (1954) "Cellular Concretes: Composition and Method of Preparation". Journal of American Concrete Institute, Vol. 2, pp. 773 - 795.
[5] CCI (2010) "Foamed Concrete" Publication of the Cement \& Concrete Institute, Midrand. http://www.cnci.org.za, assessed on, August 14, 2010.

[6] Jones, M. R. and McCarthy, A. (2005). "Preliminary Views on the Potential ofFoamed Concrete as a Structural Material". Magazine of Concrete Research, Vol. 57, No. 1, pp. 21 - 31.

[7] Pan, Z., Hiromi, F. and Wee, T. (2006) "Preparation of High Performance Foamed Concrete from Cement, Sand and Mineral Admixtures". Journal of Wuhan University of Technology, Materials Science Edition, Vol. 22 No. 2, pp. 295 - 298.

[8] Bing, C., Zhen, W. and Ning, L. (2011) “Experimental Research on Properties of High Strength Foamed Concrete". ASCE Journal of Materials in Civil Engineering,Vol. 24, pp. 113 - 118.

[9] Wittmann, F. H. (1992) "Advanced in Autoclaved Aerated Concrete". Proceedings of the $3^{\text {rd }}$ International Symposium on Autoclaved Aerated Concrete, Zurich Switzerland, October 1992.

[10] TrueStone America http//www.truestoneamerica.com/what.html assessed on February, 2013.

[11] Boido, S. C. and Caldera, C. (2002) "Potential, Limitations, and Sustainability of Autoclaved Aerated Concrete". Proceedings of Atti International Conference onSustainable Building, Oslo Norway.

[12] LightConcrete LLC (2010) "High-Strength Structural Concrete"ji@lightconcrete.com, accessed on September, 2010.

[13] Schnitzler, S. (2006) "Autoclaved Aerated Concrete as a Green Building Material" Applied Research Paper.

[14] RILEM (1978) "Functional Classification of Lightweight Concrete: Recommendations". LC 2, $2^{\text {nd }}$ Edition.

[15] ACI Committee 213 (2003) "Guide for Structural Lightweight Aggregate Concrete". American Concrete Institute, Farmington Hills, MI.

[16] NIS 444 (2003) "Standard for Cement". Standard Organisation of Nigeria, Lagos.

[17] Cox, L. and Van-Dijk, S. (2002). "Foam concrete: A Different Kind of Mix". Concrete, Vol. 36, No. 2, pp. 54.

[18] Litebuilt (2010)“Aerated Lightweight Concrete Foamed Technology Pan Pacific Management Resources PY Ltd (http://www.litebuilt.com, assessed on January, 2011.

[19] BS 1377 (1990) "Methods of Test for Soils for Civil Engineering Purposes". British Standard Institution, London.

[20] BS 12350: Part 2 (2000) "Method for Determining the Slump". British Standard Institution, London.

[21] BS 12350: Part 6 (2000) "Method for Determining of Density". British Standard Institution, London. 


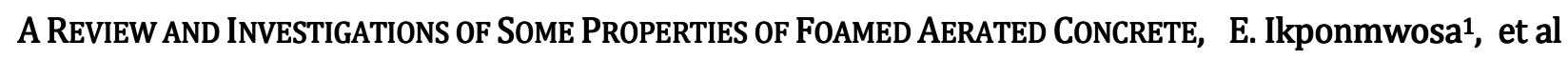

[22] BS 12390: Part 3 (2009) "Testing Hardened Concrete: Compressive Strength of Test Specimens". British Standard Institution, London.

[23] Tex-421 - A (2008) "Splitting Tensile Strength of Cylindrical Concrete Specimens". Texas Department of Transportation, Texas USA.

[24] BS 12390: Part 6 (2009) “Testing Hardened Concrete: Tensile Splitting Strength of Test Specimens". British Standard Institution, London.

[25] ASTM C72 - 02 (2000) "Standard Test Method for Flexural Strength of Concrete- Using Simple Beam with Third-Point Loading. ATM International, USA.

[26] BS 12390: Part 5 (2009) "Testing Hardened Concrete: Flexural Strength of Test Specimens". British Standard Institution, London.

[27] BS 1881 (2011) "Testing Concrete: Method for Determination of Water Absorption Capacity". British Standard Institution, London.

[28] Salau, M. A. and Olonode, K. A. (2011). "Pozzolanic Potentials of Cassava Peel Ash".Journal of Engineering Research, 16 (1): 10 -21.

[29] BS EN 12350: Part 5 (2000) "Method for determination of flow". British Standard Institution, London.

[30] Brady, K. C., Watts, G. R. A. and Jones, M. R. (2001) "Specifications for Foamed Concrete - The Use of Foamed Concrete as Backfill". QS CE Geotechnics and Ground Engineering Highways Agency, TRL Limited London.

[31] Neville, A. M. (2003) "Properties of Concrete". Pearson International, $4^{\text {th }}$ Edition.

[32] Nambiar, E. K. and Ramamurthy, K. (2008) "Fresh State Characteristics of Foamed Concrete". ASCE Materials of Civil Engineering, Vol. 20, pp. 111 117.

[33] Meena, S. K., Meena, P. K., and Meena, R. K. Roy, R. and Meena, P. K. (2012) "Foamed Concrete". http://www.intinno.iitkgp.ernet.in/ assessed on March, 2012).

[34] Atis, C. D. (2005) "Strength Properties Of HighVolume Fly Ash Roller Compacted and Workable Concrete, And Influence Of Curing Condition". Cement and Concrete Research, Vol. 35, pp. 1112 1121.

[35] Wright, J. K. and McGregor, J. G. (2009) "Reinforced Concrete: Mechanics and Design". Pearson Education International, $5^{\text {th }}$ Edition.

[36] Shetty, M. S. (2009) "Concrete Technology - Theory and Practice". S. Chand and Company Ltd.

[37] Reynolds, C. E. Steedman, J. C. and Threlfall, A. J (2008) “Reynold's Reinforced Concrete Designer's Handbook". Taylor and Francis London, $11^{\text {th }}$ Edition. 